\title{
Spontaneous resolution of pneumomediastinum in children - clinical experience
}

\author{
Klaudia Korecka', Lidia Hyla-Klekot², Mateusz Kęsek', Grzegorz Kudela', \\ Andrzej Michał Bulandra', Tomasz Koszutski ${ }^{1}$ \\ 'Department of Paediatric Surgery and Urology, School of Medicine in Katowice, Medical University of Silesia, \\ Katowice, Poland \\ 2Department of Paediatric Nephrology, Paediatrics and Oncology Centre, Chorzow, Poland
}

\section{ABSTRACT}

Introduction: Pneumomediastinum is defined as the presence of free gas in the mediastinal space and occurs with varying frequency depending on age.

Aim of the study: The aim of this study is to report a series of spontaneous pneumomediastina in a paediatric population.

Material and methods: The study is a retrospective analysis of five clinical cases of pneumomediastina in adolescent patients hospitalised in the Clinical Department of Paediatric Surgery between 2016 and 2018. Two girls and three boys with a mean age of 16.4 years were admitted to the emergency room due to dyspnoea and visible enlargement of neck circumference, which was due to emphysema of soft tissues of the neck. In three patients, chest pain was the predominant symptom. One patient presented with speech difficulties. On admission the general condition of all patients was good. Cardiovascular and respiratory efficiency was reported in all patients. The main symptom suggesting pneumomediastinum was the presence of soft tissue emphysema of the neck. Chest X-ray was performed in all patients as a preliminary examination, confirming the suspicion of pneumomediastinum. Oesophagography was performed in four patients. However, no abnormalities were detected. All patients underwent chest CT.

Results: Despite extensive changes in CT, no progression of symptoms was observed. There was no indication for surgical intervention in any patient. Complete spontaneous regression was observed in all cases between day 4 and day 21 of the follow-up. Patients were discharged home after 6-10 days of hospitalisation. No recurrence in long-term follow-up was observed. Spontaneous resolution of free gas in the mediastinum was observed in all patients.

Conclusions: Survival rates of patients with pneumomediastinum of unknown cause that do not require surgical treatment are high and reach about $92.5-100 \%$. In the vast majority of patients, spontaneous resolution is observed. The prognosis is therefore favourable, and the risk of recurrence is low.

\section{KEY WORDS:}

children, pneumomediastinum, spontaneous pneumomediastinum.

\section{ADDRESS FOR CORRESPONDENCE:}

Klaudia Korecka, Department of Paediatric Surgery and Urology, School of Medicine in Katowice, Medical University of Silesia, 16 Medyków St., 40-752 Katowice, Poland, ORCID: 0000-0001-6634-0997, e-mail: kkorecka@poczta.onet.pl 


\section{INTRODUCTION}

Pneumomediastinum is defined as the presence of free gas in the mediastinal space. The first reported case was noted by Rene Theophile Laenneco (1819), and in 1964 Theler was the first to report this pathology in a child $[1,2]$. Pneumomediastinum is a symptom that occurs with varying frequency depending on age. Current statistics indicate that the frequency is one per 40,000 emergency room visits every year [2]. Among the paediatric population two peaks of incidence are observed: early childhood (i.e. 6 months -4 years) and adolescence (i.e. 15-18 years of age) [3, 4]. Most authors indicate the age between 6 and 14 years old as the median age. The prevalence in this age group is $1 / 8000-1 / 15,000$, while in newborns it reaches 2.5/1000 [2, 3].

Pneumomediastinum can be primary - idiopathic (spontaneous pneumomediastinum; SPM), which accounts for $33-49 \%$ of cases $[1,3,4]$. Secondary pneumomediastinum is associated with the co-occurrence of additional underlying diseases. The most common conditions in children include bronchial asthma, various injuries (barotrauma, bronchial, tracheal or oesophageal perforation), iatrogenic complications (e.g. following tonsillectomy), and infections (e.g. RSV) [3, 5]. Less common causes include foreign body aspiration into the airways, severe vomiting, intensive physical effort, seizures, or the use of psychoactive drugs (designer drugs, cannabis) $[2,3,5]$.

The most common symptoms of pneumomediastinum include acute chest pain (55-90\%), subcutaneous emphysema (66-90\%), and dyspnoea (30\%), which are the components of the characteristic triad according to Crespo Marcos $[1,3,6]$. Other less common symptoms include neck or throat pain (20-53\%), oedema of the neck and face, wheezing, cyanosis, dysphonia, and cough $[1,3]$. The Hamman sign, initially reported in 1939 , is a crunching, rasping sound in the mediastinum during systole and diastole on auscultation and is relatively rare $(11.6 \%)$ [3, 7]. Occasionally, pneumomediastinum may be accompanied by pneumothorax. The coincidence rate of these conditions is about $11.6 \%$ [3]. It should be borne in mind that cardiac disorders may develop due to heart compression caused by a massive collection of gas in the mediastinum [4].

Due to the variety of causes, clinical symptoms, course, and prognosis, the diagnosis and treatment of pneumomediastinum may pose many challenges. This condition can resolve spontaneously with complete recovery or transform into life-threatening emergency.

\section{MATERIAL AND METHODS}

The study is a retrospective analysis of five clinical cases of pneumomediastinum in adolescent patients hospitalised in the Clinical Department of Paediatric Surgery between 2016 and 2018. Medical history, physical exam- ination, results of laboratory tests, imaging studies, and endoscopic procedures were analysed. The most probable causes of pneumomediastinum were presented.

Two girls and three boys with a mean age of 16.4 years were admitted to the emergency room due to dyspnoea and visible enlargement of neck circumference, which was due to emphysema of soft tissues of the neck (Table 1). In three patients, chest pain was the predominant symptom. One patient presented with speech difficulties. On admission the general condition of all patients was good. Cardiovascular and respiratory efficiency was reported in all patients. The main symptom suggesting pneumomediastinum was the presence of the soft tissue emphysema of the neck. One patient presented with a positive Hamman sign and arrhythmia. Most patients denied incidents related to excessive effort before admission. Only two patients related the onset of symptoms to sudden movement (running for the bus, PE classes at school). One patient had a history of a right collarbone fracture three weeks before admission. None of the patients was exposed to medical procedures within a month prior to admission. One patient was treated for type 1 diabetes.

None of the patients presented with active infection on admission. Inflammatory parameters in laboratory tests were analysed - WBC: $6.7 \mathrm{~K} / \mathrm{ul}, 15.5 \mathrm{~K} / \mathrm{ul}, 12.2 \mathrm{~K} / \mathrm{ul}$, $14.40 \mathrm{~K} / \mathrm{ul}, 8.7 \mathrm{~K} / \mathrm{ul}$; CRP: $7.8 \mathrm{mg} / \mathrm{l}, 1.41 \mathrm{mg} / \mathrm{l}, 4.2 \mathrm{mg} / \mathrm{l}$, $0.5 \mathrm{mg} / \mathrm{l}$, and $0.3 \mathrm{mg} / \mathrm{l}$.

Chest X-ray was performed in all patients as a preliminary examination confirming the suspicion of pneumomediastinum. Oesophagography was performed in four patients. However, no abnormalities were detected. All patients underwent chest CT (Fig. 1).

CT examination revealed:

- Patient 1: extensive pneumomediastinum surrounding the heart, aorta, superior vena cava and extending upward along the trachea and cervical vessels to the subcutaneous tissue of the right supraclavicular region and neck. Air was present in soft tissues of the throat. Microperforation of the anterior wall of the right main bronchus was suspected.

- Patient 2: extensive pneumomediastinum, subcutaneous emphysema in the neck and along the right side of the thorax. Pneumothorax in the apex of the right lung was visible. Oesophageal microperforation (in the upper part) was suspected.

- Patient 3: pneumomediastinum with massive interfascial emphysema of the neck, mediastinum, spinal canal, and epigastric region. Residual bilateral pneumothorax was visible. Tracheal microperforation at Th5 and Th6 was suspected.

- Patient 4: mediastinal emphysema, surrounding all mediastinal structures (15 mm thick in the upper mediastinum on the right side). Emphysema of the soft tissues at the base of the neck was visible.

- Patient 5: emphysema of the upper mediastinum up to $15 \mathrm{~mm}$ thick located along the trachea and heart, 
TABLE 1. Symptoms of mediastinal emphysema and the results of additional imaging examinations in patients

\begin{tabular}{|c|c|c|c|c|c|}
\hline Feature & Patient 1 & Patient 2 & Patient 3 & Patient 4 & Patient 5 \\
\hline Sex & Male & Female & Female & Male & Male \\
\hline Age (years) & 16 & 16 & 16 & 17 & 17 \\
\hline $\begin{array}{l}\text { Clinical } \\
\text { symptoms }\end{array}$ & $\begin{array}{l}\text { Dyspnoea, chest pain, } \\
\text { emphysema of the soft } \\
\text { tissues of the neck }\end{array}$ & $\begin{array}{l}\text { Dyspnoea, (+) Ham- } \\
\text { man sign, arrhythmia, } \\
\text { emphysema of the soft } \\
\text { tissues of the neck }\end{array}$ & $\begin{array}{l}\text { Dyspnoea, emphyse- } \\
\text { ma of the soft tissues } \\
\text { of the neck, neck }\end{array}$ & $\begin{array}{l}\text { Chest pain, difficulties } \\
\text { with speaking, emphy- } \\
\text { sema of the soft tissues } \\
\text { of the neck }\end{array}$ & $\begin{array}{l}\text { Chest pain, emphyse- } \\
\text { ma of the soft tissues } \\
\text { of the neck and chest } \\
\text { (presternally) }\end{array}$ \\
\hline $\begin{array}{l}\text { General } \\
\text { condition }\end{array}$ & $\begin{array}{l}\text { Good, cardiovascular } \\
\text { and respiratory effi- } \\
\text { ciency }\end{array}$ & $\begin{array}{l}\text { Good, cardiovascular } \\
\text { and respiratory efficiency }\end{array}$ & $\begin{array}{l}\text { Good, cardiovascular } \\
\text { and respiratory } \\
\text { efficiency }\end{array}$ & $\begin{array}{l}\text { Good, cardiovascular } \\
\text { and respiratory } \\
\text { efficiency }\end{array}$ & $\begin{array}{l}\text { Good, cardiovascular } \\
\text { and respiratory } \\
\text { efficiency }\end{array}$ \\
\hline $\begin{array}{l}\text { Physical } \\
\text { effort directly } \\
\text { before the } \\
\text { onset of } \\
\text { symptoms }\end{array}$ & No & No & No & No & $\begin{array}{l}\text { Intense } \\
\text { sport training }\end{array}$ \\
\hline $\begin{array}{l}\text { History of } \\
\text { trauma }\end{array}$ & No & No & $\begin{array}{l}\text { Injury to the right } \\
\text { collar bone } 3 \text { weeks } \\
\text { before admission }\end{array}$ & No & No \\
\hline \begin{tabular}{|l} 
History of \\
medical \\
interventions
\end{tabular} & No & No & No & No & No \\
\hline $\begin{array}{l}\text { Infectious } \\
\text { symptoms }\end{array}$ & $\begin{array}{l}\text { No } \\
\text { WBC } 6.7 \mathrm{~K} / \mathrm{ul} \\
\text { CRP } 7.8 \mathrm{mg} / \mathrm{l} \\
\end{array}$ & $\begin{array}{l}\text { No } \\
\text { WBC } 15.5 \mathrm{~K} / \mathrm{ul} \\
\text { CRP } 1.41 \mathrm{mg} / \mathrm{l}\end{array}$ & $\begin{array}{l}\text { No } \\
\text { WBC } 12.2 \mathrm{~K} / \mathrm{ul} \\
\text { CRP } 4.2 \mathrm{mg} / \mathrm{l}\end{array}$ & $\begin{array}{l}\text { No } \\
\text { WBC } 14.4 \mathrm{~K} / \mathrm{ul} \\
\text { CRP } 0.5 \mathrm{mg} / \mathrm{l}\end{array}$ & $\begin{array}{l}\text { No } \\
\text { WBC } 8.7 \mathrm{~K} / \mathrm{ul} \\
\text { CRP } 0.3 \mathrm{mg} / \mathrm{l}\end{array}$ \\
\hline $\begin{array}{l}\text { CT scan } \\
\text { of the chest }\end{array}$ & $\begin{array}{l}\text { Extensive pneumo- } \\
\text { mediastinum surroun- } \\
\text { ding the heart, aorta, } \\
\text { superior vena cava, and } \\
\text { extending upward along } \\
\text { the trachea and cervical } \\
\text { vessels to the subcuta- } \\
\text { neous tissue of the right } \\
\text { supra-clavicular region } \\
\text { and neck; air collection } \\
\text { in the soft tissues of the } \\
\text { throat; suspicion } \\
\text { of micro-perforation } \\
\text { of the anterior wall of } \\
\text { the right main bronchus } \\
\text { with no connection with } \\
\text { pneumo-mediastinum }\end{array}$ & $\begin{array}{l}\text { Extensive pneumo- } \\
\text { mediastinum, subcuta- } \\
\text { neous emphysema of } \\
\text { the neck and along the } \\
\text { right side of the thorax; } \\
\text { pneumothorax in the } \\
\text { apex of the right lung; } \\
\text { suspicion of oesophageal } \\
\text { micro-perforation } \\
\text { (upper part) }\end{array}$ & $\begin{array}{l}\text { Pneumo-mediasti- } \\
\text { num with massive } \\
\text { interfascial emphyse- } \\
\text { ma of the neck, } \\
\text { mediastinum, spinal } \\
\text { canal and epigastric } \\
\text { region; residual bila- } \\
\text { teral pneumothorax; } \\
\text { suspicion of tracheal } \\
\text { micro-perforation } \\
\text { (at Th5, Th6) }\end{array}$ & $\begin{array}{l}\text { Pneumo-mediastinum } \\
\text { surrounding all the } \\
\text { mediastinal structures } \\
\text { (15 mm thick in the } \\
\text { upper mediastinum } \\
\text { on the right side). } \\
\text { Emphysema of the } \\
\text { soft tissues at the base } \\
\text { of the neck. Trachea } \\
\text { and bronchi without } \\
\text { abnormalities }\end{array}$ & $\begin{array}{l}\text { Emphysema of the } \\
\text { upper mediastinum } \\
\text { paratracheally } \\
\text { along the contours } \\
\text { of the heart - } 15 \mathrm{~mm} \text {, } \\
\text { within the anterior } \\
\text { mediastinum - } \\
12 \mathrm{~mm} \text {, posterior me- } \\
\text { diastinum - } 10 \mathrm{~mm} \text {, } \\
\text { of the neck along the } \\
\text { trachea - } \\
15 \mathrm{~mm}\end{array}$ \\
\hline $\begin{array}{l}\text { Additional } \\
\text { tests }\end{array}$ & $\begin{array}{l}\text { Chest X-ray(+) } \\
\text { 0esophagography(-) } \\
\text { Alpha-1 antitrypsin(-) }\end{array}$ & $\begin{array}{l}\text { Chest X-ray(+) } \\
\text { Oesophagography(-) } \\
\text { Esophagoscopy(-) } \\
\text { Bronchoscopy (-) } \\
\text { Panel drug tests(-) }\end{array}$ & Chest X-ray(+) & $\begin{array}{l}\text { Chest X-ray(+) } \\
\text { Oesophagography(-) } \\
\text { Alpha-1 anti- } \\
\text { trypsin(-) } \\
\text { Panel drug tests(-) }\end{array}$ & $\begin{array}{l}\text { Chest X-ray(+) } \\
\text { Oesophagography (-) }\end{array}$ \\
\hline $\begin{array}{l}\text { Follow-up } \\
\text { chest X-ray }\end{array}$ & $\begin{array}{l}\text { Yes, complete resolution } \\
\text { of changes (day 21) }\end{array}$ & $\begin{array}{l}\text { Yes, complete resolution } \\
\text { of changes (day 8) }\end{array}$ & $\begin{array}{l}\text { Yes, regression } \\
\text { of changes in the } \\
\text { mediastinum } \\
\text { to } 3-5 \mathrm{~mm} \\
\text { in diameter (day 4) }\end{array}$ & $\begin{array}{l}\text { Yes, regression } \\
\text { of changes in the } \\
\text { mediastinum } \\
\text { to } 7 \mathrm{~mm} \\
\text { in diameter (day 3) }\end{array}$ & $\begin{array}{l}\text { No, evaluation in } \\
\text { Oesophagography - } \\
\text { regression of changes } \\
\text { in the mediastinum } \\
\text { to } 4 \mathrm{~mm} \text { in diameter } \\
\text { (day 2) }\end{array}$ \\
\hline Treatment & i.v. antibiotic therapy & $\begin{array}{l}\text { i.v. antibiotic therapy } \\
\text { total parenteral nutrition }\end{array}$ & i.v. antibiotic therapy & i.v. antibiotic therapy & i.v. antibiotic therapy \\
\hline \begin{tabular}{|l|}
$\begin{array}{l}\text { Discharge } \\
\text { home }\end{array}$ \\
\end{tabular} & \begin{tabular}{|l} 
Day 8 \\
of hospitalisation
\end{tabular} & \begin{tabular}{|l|} 
Day 10 \\
of hospitalisation
\end{tabular} & \begin{tabular}{|l} 
Day 6 \\
of hospitalisation
\end{tabular} & \begin{tabular}{|l} 
Day 8 \\
of hospitalisation \\
\end{tabular} & \begin{tabular}{|l} 
Day 7 \\
of hospitalisation \\
\end{tabular} \\
\hline Recurrence & No & No & No & No & No \\
\hline
\end{tabular}




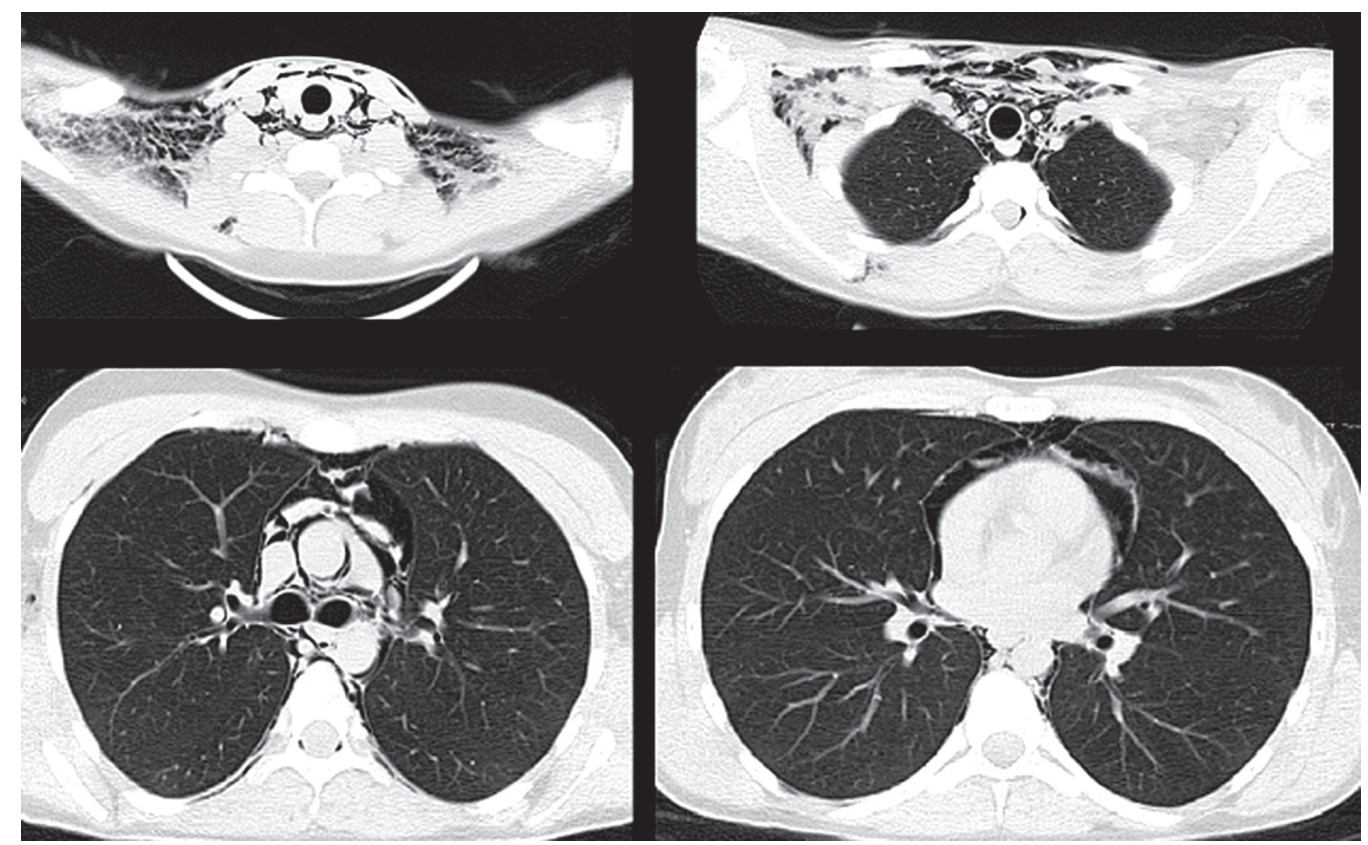

FIGURE 1. CT scans showing subcutaneous emphysema of the neck and pneumomediastinum

up to $12 \mathrm{~mm}$ in the anterior mediastinum, and $10 \mathrm{~mm}$ thick in the posterior part. Free air around the neck along the trachea was up to $15 \mathrm{~mm}$ thick.

In one patient with suspicion of oesophageal microperforation in CT, oesophagoscopy, and bronchoscopy were performed. However, these examinations did not reveal any abnormal findings.

Alpha-1 antitrypsin level test and panel drug tests were performed in two patients. Both tests were negative. Multiple consultations were performed. All patients were consulted with cardiologists, otorhinolaryngologists, and pulmonologists.

All patients were advised to rest, and intravenous antibiotic therapy (prophylaxis of mediastinitis) was applied. One patient suspected of oesophageal microperforation was also treated with short-term parenteral nutrition. $\mathrm{Pa}$ tients were constantly monitored during the follow-up. Despite extensive changes in CT, no progression of symptoms was observed. There was no indication for surgical intervention in any patient. Complete spontaneous regression was observed in all cases between day 4 and day 21 of the follow-up. Patients were discharged home after 6-10 days of hospitalisation. No recurrence was observed in long-term follow-up.

\section{DISCUSSION}

Pneumomediastinum is a condition is potentially life-threatening. Therefore, the necessity of hospital admission should always be considered. The choice of department should depend on the general condition of the patient, the necessity for surgical intervention, and any comorbidities. In the case of patients in good general condition and no gastrointestinal or bronchial perforation, the treatment can be successfully performed in a general paediatrics department. The aetiological factor should be sought because it may affect further diagnostic and therapeutic procedures. The lack of a specific cause leads to the diagnosis of spontaneous pneumomediastinum. In pre-school children SPM relatively often develops in the course of infection. The possibility of foreign body aspiration into the airways should always be excluded $[3,7]$. Even a remote possibility of foreign body aspiration should be an indication for diagnostic bronchoscopy. In adolescence the spectrum of causes of pneumomediastinum is different. In our group the mean age of patients was 16 years. Apart from one boy, all patients denied injury, intense exertion, the possibility of iatrogenic damage, paroxysmal cough, smoking cigarettes, or the consumption of psychoactive substances. Due to the growing abuse of designer drugs and other psychoactive substances among adolescents, the patients were tested for drugs and the results were negative in all cases. Performing these tests is expensive, and even positive results do not contribute to the therapeutic process.

Chest X-ray is the basic diagnostic test that allows the initial diagnosis to be determined $[3,4]$. In our group of patients, the diagnosis was based on classical X-ray image after physical examination of patients with dyspnoea. In doubtful cases, a lateral radiograph of the neck may be of value. This examination reveals subcutaneous emphysema and the prevertebral air collections (sensitivity of 95.2\%) [4]. This projection should always be performed when CT is not possible. CT is the examination of choice in this group of patients because it allows detailed assessment of the topography of the mediastinal organs in this pathology. Numerous reports confirm the diagnostic efficacy of CT (100\% sensitivity and $85 \%$ specificity) [8]. Bakhos et al. emphasize that CT allows to diagnose pneumomediastinum in $18.36 \%$ of patients with no changes in X-ray 
[5]. All patients in our group presented with extensive pathological changes in chest $\mathrm{CT}$, which did not correspond to their good clinical condition.

Due to the fact that pneumomediastinum is often considered a potential manifestation of oesophageal perforation, oesophagography or oesophagoscopy is often initially performed. However, this approach is currently widely discussed. Oesophageal perforation in paediatric patients is extremely rare $[2,5,8,9]$. There are both opponents and supporters of oesophagography in such cases [6]. In our patients these examination results were negative and did not contribute to the diagnosis.

In addition, endoscopic procedures, such as bronchoscopy or oesophagoscopy, are sometimes associated with the necessity of general anaesthesia, which may pose some risk. Such procedures can be replaced by their virtual equivalent - the reconstruction of the image obtained in CT. In our group esophagoscopy and bronchoscopy were performed only in one patient with suspicion of oesophageal microperforation in CT. In this case endoscop- ic examinations did not reveal the site of perforation. In two patients, bronchoscopy was not performed, despite the suspicion of microperforation of the right bronchus and trachea. It did not affect the course of the disease, which was favourable. Therefore, in our opinion, diagnostic methods should be limited to CT performed after chest and neck X-rays. Time to perform CT should be determined by on the general condition of the patient and progression of clinical symptoms. Even extensive pathological changes in CT combined with good general condition of the patient do not require any follow-up examinations. The use of ultrasound in the diagnosis and monitoring of pneumomediastinum is reported in the literature $[10,11]$. However, there are limitations of this method related to the subjective assessment of the image. Comparison of chest CT and ultrasound monitoring performed by one radiologist could be a reliable solution.

Survival rates of patients with pneumomediastinum of unknown cause that do not require surgical treatment are high and reach about $92.5-100 \%$. In the vast majority

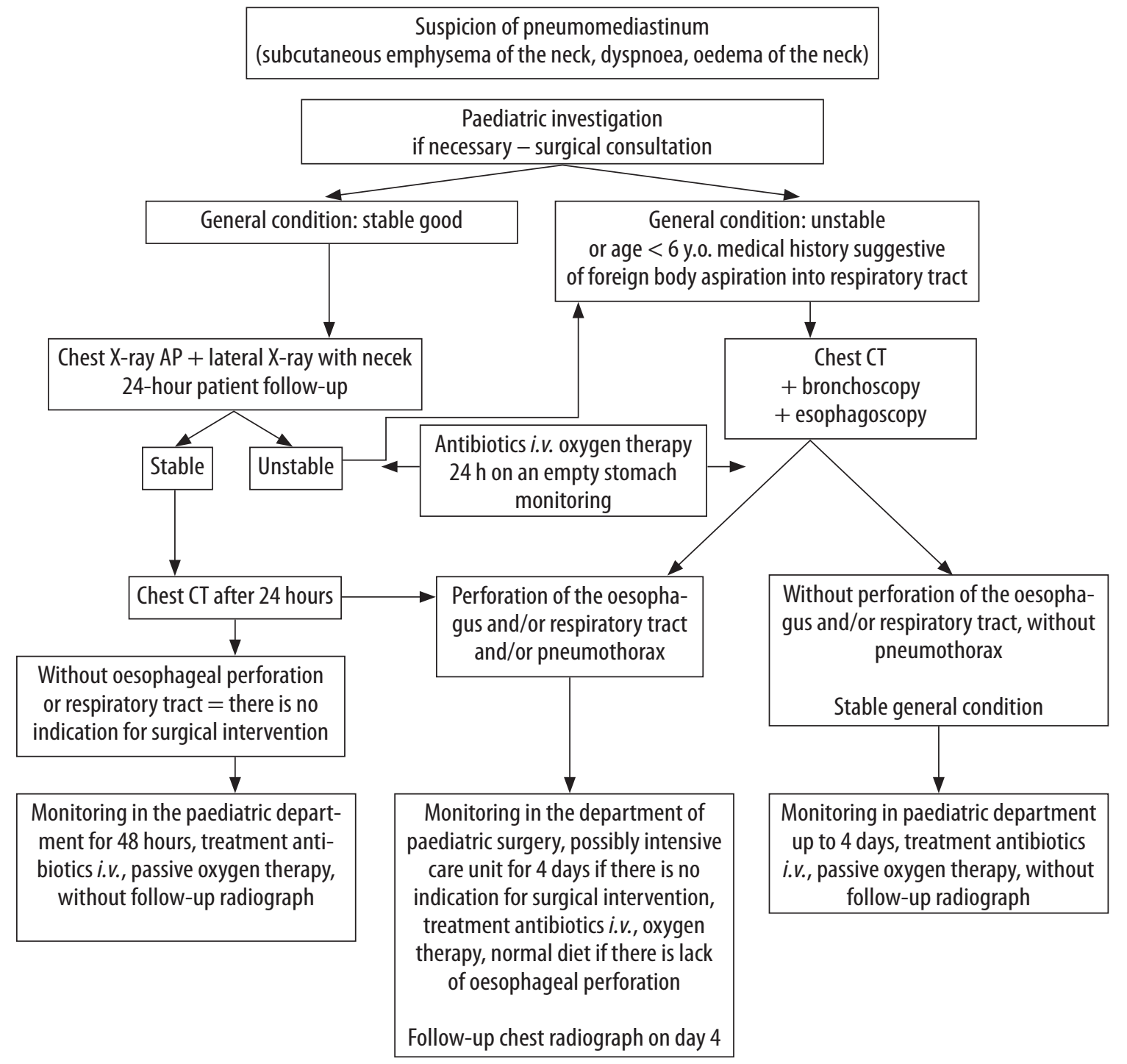

FIGURE 2. Proposal of diagnostic and therapeutic procedures in pneumomediastinum 
of patients, spontaneous resolution is observed. The prognosis is therefore favourable, and the risk of recurrence is low $[3,5]$.

Based on the available literature and our own experience with juvenile patients affected with spontaneous pneumomediastinum, the following scheme of diagnostic and therapeutic procedures can be proposed (Fig. 2).

\section{DISCLOSURE}

The authors declare no conflict of interest.

\section{REFERENCES}

1. Tortajada-Girbes M, Moreno-Prat M, Ainsa-Laguna D, Mas S. Spontaneous pneumomediastinum and subcutaneous emphysema as a complication of asthma in children: case report and literature review. Ther Adv Respir Dis 2016; 10: 402-409.

2. Fitzwater JW, Silva NN, Knight CG, et al. Management of spontaneous pneumomediastinum in children. J Pediatr Surg 2015; 50: 983-986.

3. Gasser CR, Pellaton R, Rochat CP. Pediatric spontaneous pneumomediastinum: narrative literature review. Pediatr Emer Care 2017; 33: $370-374$.

4. Wong KS, WU HM, Lai SH, Chiu CY. Spontaneous pneumomediastinum: analysis of 87 pediatric patients. Pediatr Emer Care 2013; 29: 988-991.

5. Bakhos CT, Pupovac SS, Ata A, et al. Spontaneous pneumomediastinum: an extensive workup is not required. J Am Coll Surg 2014; 219: 713-717.

6. Crespo-Marcos D, Fernandez CI, de la Plata LM, et al. Spontaneous idiopathic pneumomediastinum: apropos or a case. An Pediatr (Brac) 2006; 64: 106-107.

7. Lee CY, Wu CC, Lin CY. Etiologies of spontaneous pneumomediastinum in children of different ages. Pediatr Neonatol 2009; 50 : 190-195.

8. Wu $\mathrm{CH}$, Chen $\mathrm{CM}$, Chen $\mathrm{CC}$, et al. Esophagography after pneumomediastinum without CT findings of esophageal perforation: is it necessary? AJR Am J Roentgenol 2013; 201: 977-984.

9. Richer EJ, Sancez R. Are esophagrams indicated in pediatric patients with spontaneous pneumomediastinum? J Pediatr Surg 2016; 51: 1778-1781.

10. Ng L, Saul T, Lewiss RE. Sonographic evidence of spontaneous pneumomediastinum Am J Emerg Med 2013; 31: 462.e3-4.

11. Stone MB, Chilstrom M, Chase K, Lichtenstein D. The heart point sign: description of a new ultrasound finding suggesting pneumothorax. Acad Emerg Med 2010; 17: 149-150. 